\title{
Exploring What Lies Ahead in the Field of Disinfecting Coronavirus
}

\author{
Djamel Ghernaout ${ }^{1,2^{*}}$, Noureddine Elboughdiri ${ }^{1,3}$ \\ ${ }^{1}$ Chemical Engineering Department, College of Engineering, University of Ha'il, Ha'il, Saudi Arabia \\ ${ }^{2}$ Chemical Engineering Department, Faculty of Engineering, University of Blida, Blida, Algeria \\ ${ }^{3}$ Chemical Engineering Process Department, National School of Engineering, Zrig Gabes, University of Gabes, Gabes, Tunisia \\ Email: *djamel_andalus@hotmail.com
}

How to cite this paper: Ghernaout, D. and Elboughdiri, N. (2021) Exploring What Lies Ahead in the Field of Disinfecting Coronavirus. Open Access Library Journal, 8: e7487.

https://doi.org/10.4236/oalib.1107487

Received: May 2, 2021

Accepted: May 25, 2021

Published: May 28, 2021

Copyright $\odot 2021$ by author(s) and Open Access Library Inc.

This work is licensed under the Creative Commons Attribution International License (CC BY 4.0).

http://creativecommons.org/licenses/by/4.0/

(c) (i) Open Access

\begin{abstract}
Recently, huge awareness has been accorded to potential circulation of SARS$\mathrm{CoV}-2$ through water systems. This work deals with this problem and researches the behavior of coronaviruses (CoVs) in water media, with specific interest on the new data on the fresh SARS-CoV-2. The examination of the natural persistence of $\mathrm{CoVs}$ and the performance of the disinfection technologies are also discussed. All CoVs have a restricted stability in water media: 2 - 5 days in tap water and $2-6$ days in wastewater were judged enough for $2-\log$ reduction of SARS-CoV-2 titer. SARS-CoV-2 is distinguished by a weak construction and is vulnerable to traditional disinfection technologies that have been demonstrated to be very efficient in their neutralization. Approximately $5 \mathrm{~min}$ of exposure to sodium hypochlorite (1\%), ethanol (70\%), iodine (7.5\%), soap solution and additional usual disinfectants was enough for reaching 7 - 8-log of SARS-CoV-2 titer decrease. Thermal treatment is efficacious in SARS-CoV-2 demobilization: $30 \mathrm{~min}$ at 56 or $5 \mathrm{~min}$ at $70^{\circ} \mathrm{C}$ were enough for attaining the total depletion of the infectivity. Further, SARS-CoV-2 remains vulnerable to sunlight and quickly demobilized by UV radiation. $\mathrm{UV}-\mathrm{C}$ at $254 \mathrm{~nm}$ and intensity of $2.2 \mathrm{~mW} / \mathrm{cm}^{2}$ yields $3-\log$ of SARS-CoV-2 titer decrease in less than $3 \mathrm{~s}$ of application. Consequently for SARS-CoV-2 disinfection, usual injections of killing agents remain required for sanitation and for wastewater treatment. Relating to controlling CoVs diffusion and applying disinfection technologies, vigilance remains essential.
\end{abstract}

\section{Subject Areas}

Chemical Engineering \& Technology

\section{Keywords}

Coronaviruses (CoVs), Severe Acute Respiratory Syndrome Coronavirus-2 
(SARS-CoV-2), SARS-CoV-2 Stability, Disinfection, Microorganisms (MOs), Wastewater Treatment Plants (WWTPs)

\section{Introduction}

At the end of 2019, a fresh human coronavirus (CoV), called severe acute respiratory syndrome coronavirus-2 (SARS-CoV-2), was discovered in Wuhan (China) [1]. SARS-CoV-2 has provoked an epidemic of respiratory illness named COVID-19 [2] [3]. SARS-CoV-2 is a member of the Coronaviridae family that includes enveloped and single-stranded ribonucleic acid (RNA) viruses with sizes ranging from 60 to $220 \mathrm{~nm}$ [4] [5] [6]. Surrounding the viral RNA, the viral protein capsid is enveloped by a lipid bilayer membrane that holds proteins or glycoproteins and crown-like spikes on the surface [7] [8]. CoVs could contaminate birds, rodents, felines, canids, chiropters, and other mammals comprising humans [9] [10] [11]. Related to the zoonotic transmission, the first animal-to-person transfer of $\mathrm{CoV}$ seems to have happened through a natural genetic mutation authorizing the virus to pass infection to human beings [9] [12] [13]. In due course, the person-to-person transfer took place via inhaling infected aerosols and respiratory droplets [14] [15]. Nevertheless, additional probable ways of SARS-CoV-2 transmission have been proposed comprising transmission via fomites [16], ocular surfaces [17] and the fecal-oral path [18] [19].

During the 1960s, CoVs were primarily recognized and until now seven human CoVs have been mentioned [1]. Three of them spectacularly appeared lately: SARS-CoV, Middle East respiratory syndrome-CoV (MERS-CoV), and SARS-CoV-2 [1]. Controlling human mortality related to CoVs transmission and the number of people needing hospitalization imposes the implementation of rigorous isolation actions in the regions touched by the contagion. Throughout outbreaks, the elevated rate of transmission of human CoVs has mainly happened by the transfer of infected respiratory droplets [1] [14] [15]. Prior the arrival of SARS-CoV (below designated as SARS-CoV-1 to avert confusion with the SARS-CoV-2) during 2002 (in China), CoVs were seen as solely respiratory pathogens. Nevertheless, SARS-CoV-1 could also touch the human enteric tract [20]. Wastewater could be immediately polluted with CoVs through contaminated feces [21]. It is well-known that CoVs stay in water from few hours to few weeks, even if their viability and infectivity highly rely on many parameters.

It is hard to estimate the influence of waterborne viral infections, so the action of such infections is frequently disregarded as was the case during the SARS epidemic in Hong Kong in 2003 [1]. Bioaerosols, formed from the aeration in sewer pipelines and not subject to particular disinfection treatments, were recognized to be source of the SARSCoV-1 spreading in Amoy Gardens (a private housing estate in Hong Kong) [22]. The random sharing of ponds by ducks, pigs and humans was mentioned as origin and hot spots of resurgence of the in- 
fluenza A virus subtype H5N1 (an enveloped virus with spike-like proteins on surface similar to those of CoVs) [23]. The spillover transmission of H5N1 virus to humans happened from ducks, the original host species for the virus, through pigs as an intermediate species [23]. Animals have as well been confirmed to be reservoirs for the fresh SARS-CoV-2. Indeed, the virus has been observed to be efficiently replicant in cats and ferrets and comparatively and poorly replicant in dogs, pigs, chickens and ducks [1].

SARS-CoV-2 has been very quickly catching throughout the globe [1] [3] [24]. Likewise to respiratory dysfunctions, the virus causes grave enteric symptoms and has been observed in the feces of contaminated patients [3] [25]. Therefore, the digestive system has been seen as a possible way of contagion [3] and the virus RNA finished in wastewater. Urine and feces of patients touched by COVID-19 have been demonstrated epidemic, via assessing the viable SARSCoV-2 virus particles in suitable host cells [26]. Nonetheless, regardless of the elevated levels of the RNA of the virus throughout the globe detected in wastewaters and the possible worries associate, new studies on the infectivity have pointed out a rare perseverance of the virus in such aquatic media [1] [27].

On the contrary, information on the presence of SARS-CoV-2 traces in wastewater could be employed by epidemiologists and government authorities for estimating the magnitude of propagation of the virus in the population associate to a water sanitation network [1] [2]. Numerous nations have started national wastewater surveillance programs [1].

Because of the likely diffusion of the virus through wastewater, its occurrence in this aquatic media represents a possible risk [28] [29] [30]. Furthermore, observing virus diffusion furnishes a strong tool in the hands of the scientific and health communities, as an epidemiological measure of the propagation of the virus, comprising the number of asymptomatic infections. In such circumstance, it is crucial the understanding of the state-of-the-art on the techniques for detection, quantification and determination of infectivity of the virus in aqueous matrices. The perception of the virus in wastewater is not directly related to the infectivity. Thus, Buonerba et al. [1] examined the technique for determination of the viable SARS-CoV-2 virions and the assessment of the probable hazards related.

As seen above, a great interest is accorded on the likely propagation of SARSCoV-2 through water systems. This work aims to review the fundamental comprehension of behavior and persistence of the SARS-CoV-2 in water. Besides this grasp, understanding performance of the processes for disinfecting water authorizes establishing veritable hazards and the precise procedure for dealing with the expansion of virus through the water environment.

\section{Natural Persistence of CoVs}

The comprehension of the natural stability of pathogenic microorganisms (MOs) and the performance of usable disinfection processes render it easy to evaluate the dangers related to a contagion [1] [31] [32]. 
Recently, aerosol persistence of CoVs (especially SARS-CoV-2) has been largely examined [33] [34] [35]. The usual demobilization of CoVs in the nature is a function of numerous parameters like temperature, relative humidity and, in water media, on pH, level of particulate, organic matter [36] [37] [38], chemicals, and of antagonistic MOs [1] [39] [40].

\subsection{Persistence of CoVs on Inanimate Surfaces}

It was pointed out that inanimate surfaces are possible sources of $\mathrm{CoV}$ infection. Such contagion may be both directly (via fomite transmission) and indirectly (via water media which came into contact with the infected surface) [1]. Further, the aerosolization of fomites has been showed to be efficient in the circulation of viruses like the Influenza A virus [1]. Therefore, in such circumstances it is vital to establish the stability of CoVs on different surfaces and the sufficiency of disinfection implements utilized to treat them [41] [42]. Following the natural circumstances, human CoVs have the potential to stay contagious on inanimate surfaces from $2 \mathrm{~h}$ up to even several weeks [1].

\subsection{Persistence of CoVs in Water}

Humans need water for their daily activities (e.g., drinking, personal hygiene, washing, irrigation, food production, and recreational objectives) [43] [44] [45] (Figure 1). Utilized water (comprising stormwater and runoffs) is in the end gathered as wastewater [1] [46] [47]. Feces, urine, or vomit contaminated with pathogenic MOs come in the human sewage polluting consequently the urban water cycle [48] [49] [50]. Understanding the stability of those pathogens in
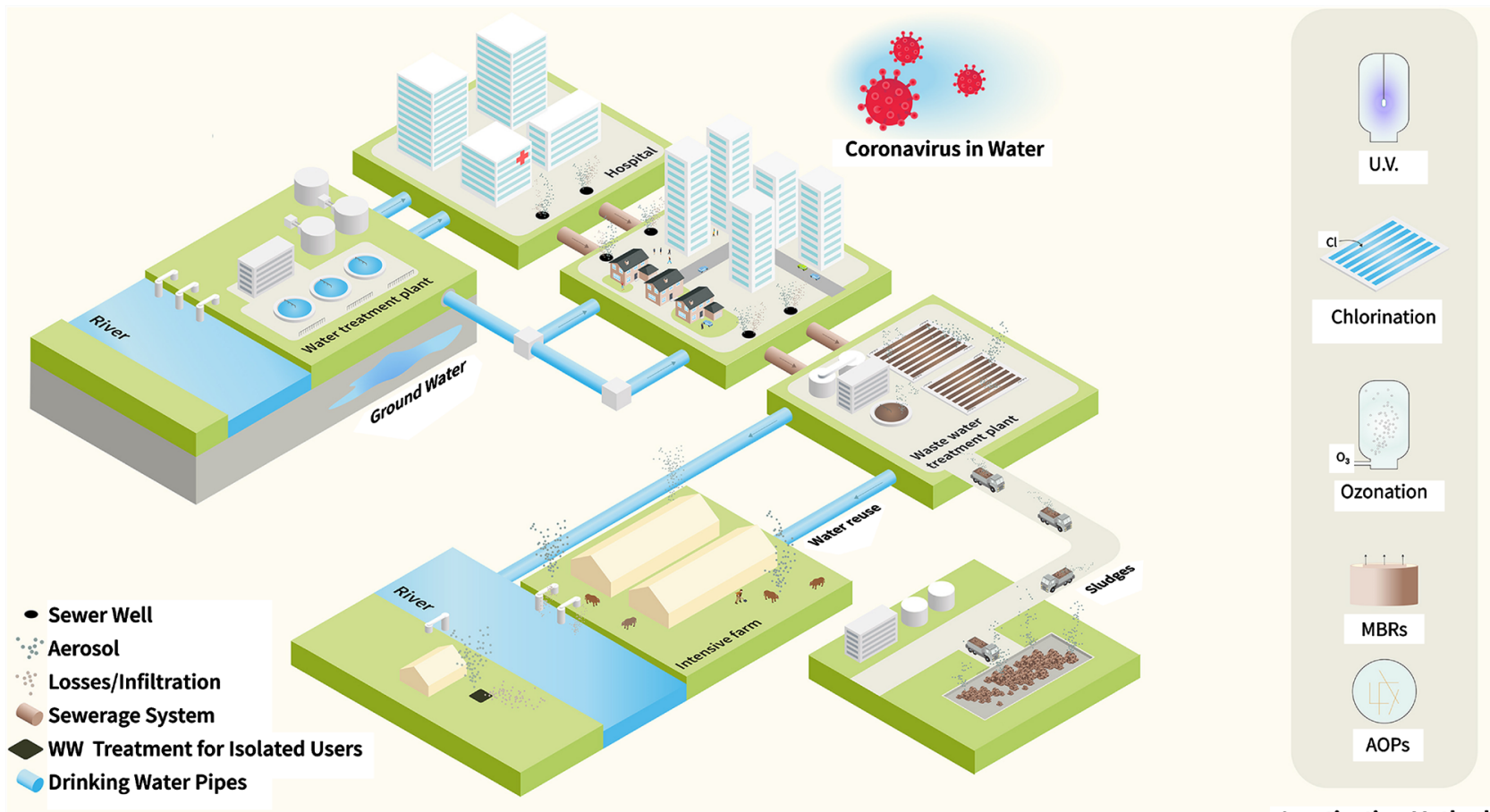

Inactivation Methods

Figure 1. Integrated water cycle [1]. 
water permits to determine exactly the concentrations of dangers for both human beings and nature [51] [52] [53]. It is well-known that the formation of bioaerosols in aeration basins in wastewater treatment plants (WWTPs) forms a danger of contamination especially of enteric viruses [54] [55]. Researchers have explained that field workers are exposed to contagions from bioaerosols [56]. Studies affirmed that the existing disinfection methods employed in WWTPs (like oxidation with hypochlorite [57] [58] [59] or peracetic acid and demobilization by ultraviolet (UV) irradiation) were enough to keep safe the health of WWTP operators and the public [1] [60] [61].

Typical CoVs (like human CoV 229E, cause of a frequent cold, and the feline infectious peritonitis virus (FIPV)) were tested defining the $\mathrm{T}_{99.9}$ (the period needed for the virus titer to decrease of 3-log (99.9\%)) [1]. Such virus titer decrease was noted in dechlorinated and filtered tap water in 10 days at $23^{\circ} \mathrm{C}$ and in 130 days at $4^{\circ} \mathrm{C}$. Demobilizing such CoVs happened faster in wastewater with a $\mathrm{T}_{99.9}$ of only 2-4 days. Below the identical circumstances, a non-enveloped virus (like the Poliovirus 1) was more solid than CoV 229E and FIPV [1]. CoV 229E depicted an identical persistence with 5-log of titer reduction during 9 days when suspended in minimum essential medium (MEM) containing antibiotics (penicillin and streptomycin), both in the presence and absence of $10 \%$ of fetal bovine serum. In a dried form, deposed on a polystyrene petri dish, $72 \mathrm{~h}$ were required [62].

The evaluation of viable virions of two surrogate CoVs, transmissible gastroenteritis virus (TGEV) and murine hepatitis virus (MHV), was performed in reagent grade water, lake water, and pasteurized settled sewage by determining the $\mathrm{T}_{99}$ (in turn corresponding to $2 \log$ ) [39]. Therefore, 2-log of virus titer decrease was noted at $25^{\circ} \mathrm{C}$ for TGEV and $\mathrm{MHV}$ in reagent grade water respectively in 22 and 17 days; while at $4^{\circ} \mathrm{C}$, no notable decrease of the contagious titer for both viruses was noticed for 49 days. In a lake water sample at $25^{\circ} \mathrm{C}$, the identical infectivity decrease was discovered for TGEV and $\mathrm{MHV}$ respectively in 13 and 10 days. At $4^{\circ} \mathrm{C}, 1$-log of titer reduction of TGEV was attained in 14 days, while the MHV resulted in comparison more persistent. In pasteurized settled sewage at $25^{\circ} \mathrm{C}, 9$ and 7 days were indispensable for 2-log of TGEV and MHV titer reduction, respectively [1].

The natural demobilization of SARS-CoV-1 in water, feces, and urine was tested in vitro [1] [63]. The virus titer was observed decreased of 5-log after 2 days at $20^{\circ} \mathrm{C}$ in dechlorinated tap water, domestic sewage, or hospital sewage; after 3 days in feces and 17 days in urine. By decreasing the temperature to $4^{\circ} \mathrm{C}$, the infectivity of SARS-CoV-2 continued for over 14 days in such media. Wet human specimens (blood serum, sputum, stool and urine) and biological media for cell and virus culture maintain quite well the infectivity of SARS-CoV-1 [62] [63] and that of other human CoVs [1]. The virus titer was decreased by 5-log in serum and sputum in $96 \mathrm{~h}$ and in urine in $72 \mathrm{~h}$ [1]. A slow rate of decrease of the titer at room temperature for SARS-CoV-1 of $0.5-\log$ reduction over 9 days was 
noted in serum-free cell culture medium, while below the identical circumstances, CoV E229 lost its infectivity totally. Phosphate-buffered saline solution at $\mathrm{pH} 7.4$ was demonstrated to guarantee valid persistence to CoVs. In such medium, E229 and OC43 remained during 3 days [64], whereas for SARS-CoV-1 over 14 days were requested for 5-log of virus titer decrease [63]. Recently, Chin et al. [65] established that SARS-CoV2 is very persistent at $4^{\circ} \mathrm{C}$ in virus transport medium: 0.7-log of titer reduction was noted after 14 day.

CoVs could remain alive during 2-4 days in wastewater at room temperature and for a more prolonged time at lower temperatures like that of the winter [21] [39] [63]. The new SARS-CoV-2 was revealed infective in human stool samples [66] and observed through the globe in wastewater and surface water receiving wastewater [1]. The RNA of the virus was discovered in sewage during and even before the appearance of COVID-19 cases [67] [68]. Nonetheless, for the determination of viable viruses in WWTP influent and effluent wastewater, as well as in hospital wastewater and in river receiving contaminated wastewater, experiments proved the restricted resistance of the virus in those water media. The findings show that the latter water medium is mostly aggressive for SARS-CoV-2. Infecting wastewater with SARS-CoV-2, researchers [27] mentioned a persistence of 1.4 - 3.3 days for 1-log and of 2.9 - 6.5 days for $2-\log$ of inactivation of the virus in this media. Nonetheless, these scientists noted an identical resistance for the virus in tap water. Indeed, at ambient temperature, the unforced decrease of the virus titer of 1-log and 2-log happened during $1.8-2.2$ and $3.6-4.4$ days, respectively [1]. Such result further asserts the restricted persistence of this virus in water media.

\section{Techniques for Demobilization of CoVs}

Lipid-enveloped viruses with elevated hydrophobicity [69] (like CoVs) remain less stable in water when juxtaposed to non-enveloped viruses (Figure 2) [1]. Ostensibly, the efficiency of water sanitation techniques for CoVs could be assessed founded on the demobilization information of non-enveloped viruses with greater durability. Unlikely, the estimation of infectivity founded just on determination of viable CoVs in wastewaters is very simplified. The present guidelines for wastewater sanitation comprise the next important options: 1) thermal treatment [70], 2) UV irradiation [71] [72], 3) chemical disinfection [73] [74] [75], 4) holding wastewater for a prolonged time [76] [77] [78]; 5) sedimentation [79] [80] [81]; 6) membrane filtration [82] [83] [84]; and 7) attenuation in subsurface [1] [85]. The efficiency of such disinfection techniques concerning CoVs (especially SARS-CoV-2) from drinking water to wastewater effluent is reviewed in this Section.

\subsection{Thermal Demobilization}

Temperature is viewed as one of the most powerful parameters for demobilizing enveloped virus [62] [86] [87]. This is related to the fact that membrane and 


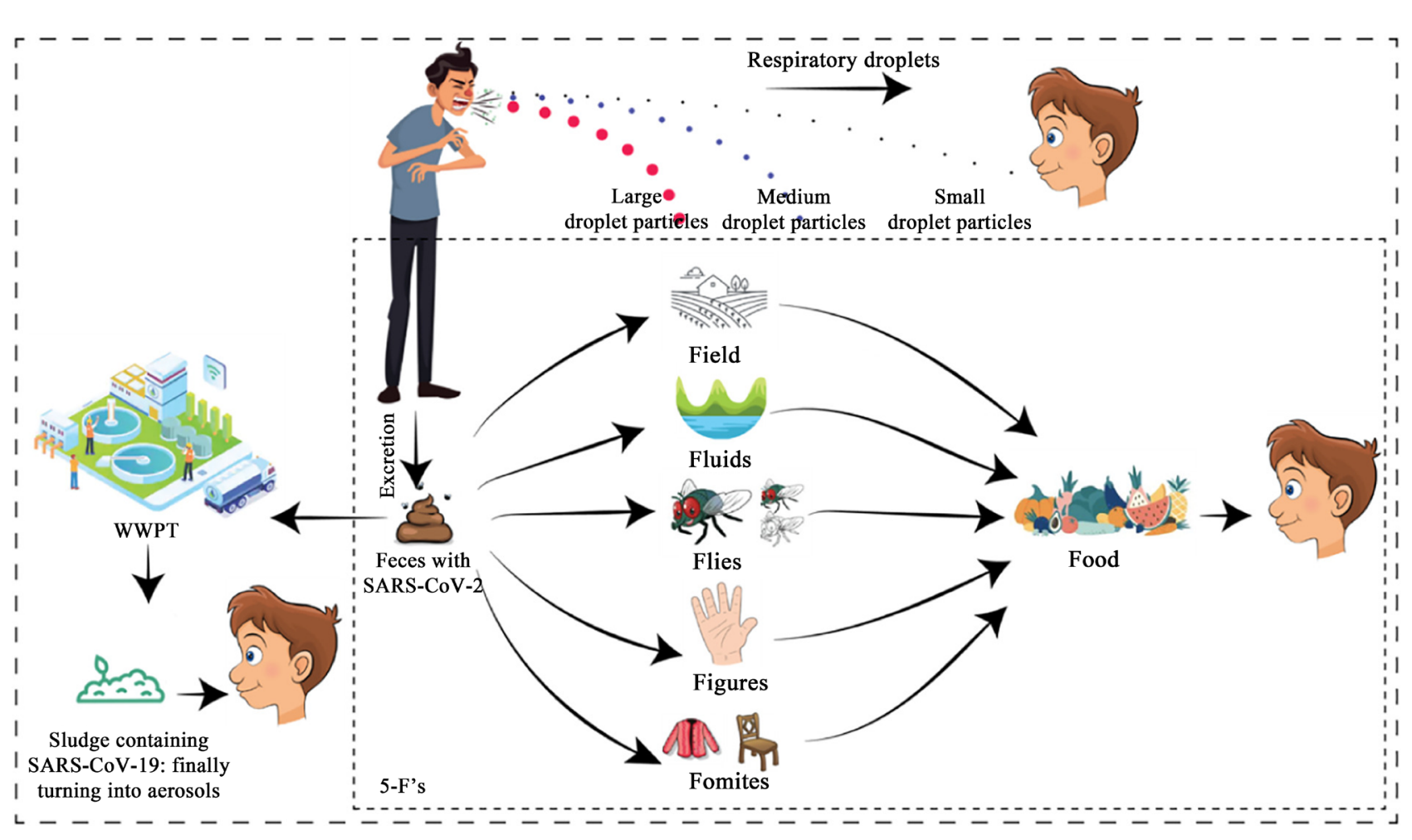

Figure 2. Schematic representation of SARS-CoV-2 spread via the fecal-oral route [33].

capsid proteins are vulnerable to heat-induced denaturation [1]. Aqueous foods (e.g., milk and fruit juice) and potable water could be treated in pasteurization methods at moderate $\left(56^{\circ} \mathrm{C}-65^{\circ} \mathrm{C}\right.$ for $\left.30 \mathrm{~min}\right)$ or high temperature $\left(80^{\circ} \mathrm{C}\right.$ $135^{\circ} \mathrm{C}$ for $1-4 \mathrm{~s}$ ), with a view to destroy or demobilize MOs, enzymes and viruses. Killing SARS-CoV-1 (-6-log) was realized at $56^{\circ} \mathrm{C}, 67^{\circ} \mathrm{C}$, and $75^{\circ} \mathrm{C}$, respectively within 90,30 , and $30 \mathrm{~min}$ [1]. Identical findings were mentioned on thermal inactivation of SARS-CoV-1 in vitro in media for cell or virus culture [62] [86]. A non-human $\mathrm{CoV}$ (the canine coronavirus (CCoV)) was observed to be contagious even at $56^{\circ} \mathrm{C}$; nonetheless, it was demobilized at temperatures higher than $65^{\circ} \mathrm{C}[88]$.

The controversy about the impacts of environment temperature on the rate of transmission of SARS-CoV-2 stays still open [89] [90]. However, the neutralizing influence of heat on the virus is not questioned [1] [70] [91]. Chin et al. [65] examined the thermal influence on the infectivity of SARS-CoV2 in virus culture media at $56^{\circ} \mathrm{C}$ and $70^{\circ} \mathrm{C}$, establishing that treatments of $30 \mathrm{~min}$ and 5 min were respectively enough for attaining 6-log of virus demobilization. In wastewater, 2-log of virus reduction was achieved at $50^{\circ} \mathrm{C}$ during $28-34 \mathrm{~min}$; whilst $70^{\circ} \mathrm{C}$ was observed adequate for $3.7-5.7 \mathrm{~min}$ [27].

\subsection{Demobilization by Ultraviolet (UV) Radiation}

Presently, demobilizing pathogens via ultraviolet (UV) radiation becomes largely used for disinfecting surfaces, potable water, as well as in tertiary treatments of wastewater for the reduction of the loading of highly resistant species [92] [93] 
[94]. A comparatively big number of the viruses, in most cases enteric ones (like noroviruses, rotaviruses, reoviruses, sapoviruses, astroviruses, enteroviruses, and adenoviruses) remain in the effluent of full-scale WWTPs with less than 2-log of loading removal [1] [95] [96]. Different from the aforesaid viruses, enveloped viruses seem to be more sensible to UV subjection. An extended subjection period of $40-60 \mathrm{~min}$ was requested to reach a favorable level of demobilization for SARS-CoV-1 in vitro [86] [97]. Kariwa and Fujii [97] revealed 5-log of SARS$\mathrm{CoV}-1$ decrease at $134 \mu \mathrm{W} / \mathrm{cm}^{2}$ in $15 \mathrm{~min}$ and further 1-log after additional 45 $\min$.

Scientists found SARS-CoV-2 vulnerable to sunlight [1] [98] [99] and fast demobilized by UV-C $(\lambda=100-280 \mathrm{~nm})$ [100] [101], UV-B $(\lambda=280-315 \mathrm{~nm})$ and UV-A $(\lambda=315-400 \mathrm{~nm})$ radiation [98]. Scientists [101] determined in vitro the kinetics and the light fluence for SARS-CoV-2 demobilization by UV-C at $\lambda$ $=254 \mathrm{~nm}$ and light intensity of $2.2 \mathrm{~mW} / \mathrm{cm}^{2}$. The reduction of 3-log of viruses was noted in less than $3 \mathrm{~s}$ of irradiation, while for $5-\log$ of demobilization were needed almost $50 \mathrm{~s}$.

\subsection{Chemical Disinfection}

Traditional antiseptics and disinfectants, like halogenated compounds (chlorine, sodium hypochlorite, chloramine and povidoneiodine), alcohols (ethanol and 2-propanol), aldehydes (formaldehyde and glutaraldehyde), quaternary ammonium compounds, phenolic compounds, and other decontaminating agents, have been observed to be efficient in disinfecting the surfaces polluted by $229 \mathrm{E}$ and SARS- and MERS-CoVs [1]. The chemicals put out the infectivity during a short subjection period of $1 \mathrm{~min}$ [62] [102]. A considerable SARS-CoV-1 titer decrease of 1.6 - 5-log was noticed in vitro testing for 0.5 - 2 min utilizing disinfectants, like 2-propanol, formaldehyde, glutaraldehyde, Desderman, Sterillium, and Incidin plus [62] and of 6-log by employing for 1 min commercially available disinfectant as povidone-iodine, isodine ${ }^{\circledR}$ solution, Isodine Scrub ${ }^{\circledR}$, Isodine Palm ${ }^{\circledR}$, Isodine Gargle ${ }^{\circledR}$ and Isodine Nodo Fresh ${ }^{\circledR}$ [97]. Traditional disinfectants, like sodium hypochlorite (1:99), ethanol (70\%), iodine solution (7.5\%), chloroxylenol $(0.05 \%)$, chlorhexidine $(0.05 \%)$ and benzalkonium chloride $(0.1 \%)$, were observed efficient in demobilizing SARS-CoV-2 in 5 min of treatment, with exception of the soap that requested bigger period for the reduction of $7-8-\log [1]$.

Researchers tested the impact of $\mathrm{pH}$ on the persistence of CoVs for CoV 229E [103], MHV [104], TGEV [105], and the CCoV [88]. Because of the lipid acidic envelope, CoVs were discovered to be responsive to the change of $\mathrm{pH}$ and the bigger virus solidity was noted at slightly acidic pH degrees of 6 - 6.5 [106]. Reciprocally, SARS-CoV-2 was observed extremely persistent in a large domain of pH levels (3 - 10) at ambient temperature [1] [65].

Founded on the information acquired from other viral indicators, employing chlorine for water disinfection remains the most efficient and economical solution for such issue [107] [108] [109]. Chlorine efficiently demobilizes the virus 
via demolishing the viral envelope or capsid [58] [59] [76]. Specially, free chlorine has been confirmed to touch directly the proteins existing in the viral envelope, rather than the less reactive lipidic material and the RNA core [1] [110] [111]. Further, chlorine could react with the ammonia existing in wastewater to generate combined chlorine such as chloramines [112] [113] [114]. Such chemicals possess the potential to kill pathogens, even if throughout disinfection they are less performant and behave diversely from free chlorine [115] [116] [117]. As a consequence, it remains fundamental for every WWTP to assess the chlorine species and their relative abundance throughout the disinfection stage [118] [119] [120].

Researches of the treatment of municipal water and wastewater utilizing chlorine and its derivatives have affirmed notable demobilization performances for SARS-CoV-1 [1] [121] [122]. In hospital wastewater, domestic sewage, and dechlorinated tap water, the virus remained active only for 2 days [1] [31]. In addition, SARS-CoV-1 became more sensitive to disinfectants juxtaposed to Escherichia coli and f2 phage. For SARS-CoV-1 demobilization, free chlorine was more efficient juxtaposed to chlorine dioxide. Free residual chlorine exceeding $0.5 \mathrm{mg} / \mathrm{L}$ or chlorine dioxide exceeding $2.19 \mathrm{mg} / \mathrm{L}$ in wastewater secured the total demobilization of SARS-CoV [1]. In addition, extreme $\mathrm{pH}$ degrees (i.e., $\mathrm{pH}>12$ or $\mathrm{pH}<3$ ), formalin, and glutaraldehyde were confirmed to demobilize SARS-CoV-1 quite well [123]. Peracetic acid has been established to possess the capacity to demolish some non-enveloped viruses (like norovirus) that are known to be more resistant to chemical agents juxtaposed to enveloped viruses [124] [125] [126].

The certified occurrence of SARS-CoV-2 RNA in wastewater influents and sludge, as well as in effluents released from WWTPs have elevated the worry of the personnel of the WWTPs [1].

Investigations have proved that the virus is inclined to show restricted resistance in wastewater [1] [27]. As a rule, studies on viable SARS-CoV-2 in real influents and effluents, both from domestic and hospital sewages, have conducted to negative findings [1] although the RNA molecules of the virus have been demonstrated to be greatly stable, even up to 50 days in wastewater at ambient temperature [27]. Worries have as well been elevated because of the environmental dangers related to an immoderate usage of disinfectants for wastewater, such as the sodium hypochlorite that forms high levels of disinfection by-product residuals [127] [128] [129].

\subsection{Impacts of Wastewater Holding}

The viral envelope of CoVs may be compromised by solvents, detergents and disinfectants, commonly existing in wastewater [1] [28] [91]. Furthermore, throughout the biological treatment step in WWTPs [48] [49] [130], the occurrence of antagonistic MOs could boost the demobilization rates of numerous viruses [30] [87] [131]. 
It is well-known that the analysis of bacteriophages furnishes a convenient index for the behavior of enveloped viruses in sewages [21] [32] [132]. The instant demobilization of bacteriophage $\Phi 6$ was adopted as a tolerable model for the survival and demobilization of enveloped human viruses [1] [133]. Such virus endures demobilization of 5-log in 2 and 6 days at $22^{\circ} \mathrm{C}$ and $30^{\circ} \mathrm{C}$, respectively. Greater holding periods, as safety measure, has to be considered at lower temperatures [50] [51] [134]. Surprisingly for a more aggressively enveloped virus (e.g. Ebola), scientists suggested holding wastewater in a reservoir for 7 days prior to further handling or transport as holding wastewater assisted diminish the viral activity [1] [52] [53].

Without disinfection applications, SARS-CoV-1 has been proved to keep its infectivity in municipal and hospital wastewater until 2 days at $22^{\circ} \mathrm{C}$ and for over 14 days at $4^{\circ} \mathrm{C}$ [1]. A decreased stability of the virus was mentioned in hospital wastewater in which is usually existing an elevated amount of disinfectants [1].

Regardless of the restricted resistance of the SARS-CoV-2 in sewages, fecal-tooral way and aerosolization of these media may take place in the circulation of the virus [1]. The aerosolizations of contaminated urines and feces from sewage pipelines, as well as throughout the washing of urinals and toilettes, have been signaled as possible courses of SARS-CoV-2 transmission [34].

\subsection{Sedimentation and Demobilization in Bioreactors}

Suspended solids [135] and particulate organic matter [36] [37] [136] in both water and wastewater participate in the physical protection of viruses, which could extend the infectivity of CoVs [1] [137] [138]. When the virus is adsorbed on the porous surface of the particulate, perhaps, it will be sterically preserved from the arid of hostile pathogens. Indeed, the elevated concentrations of suspended solids and organic matter in primary wastewater ensure extended viral infectivity with respect to secondary wastewater effluents [1] [57] [139]. Nonetheless, the elimination of suspended solids jointly with the adsorbed viruses via sedimentation guarantees the decrease of infectivity [1] [79] [140]. Researchers found that CoVs demobilization in filtered tap water resulted bigger than that in unfiltered samples [1].

Membrane bioreactors (MBRs) possess a considerable contribution in eliminating particulate matter, comprising viruses [1] [83] [141]. Enveloped viruses could be efficiently demobilized in MBRs [1] [130] [142]. Suspended solids and viruses could be hold utilizing membrane filtration even if in the occurrence of hostile pathogens and unfavorable physicochemical circumstances (like aeration [143] [144] and chemical dosing [145] [146] [147]) in the MBRs [1] [129] [148]. Such attachment conducts to the performant demobilization of enveloped viruses like CoVs [1].

\section{Conclusions}

This work discussed the fundamental comprehension of behavior and persis- 
tence of the SARS-CoV-2 in water. Further, understanding performance of the disinfection technologies authorizes establishing veritable hazards and the precise procedure for dealing with the expansion of virus through the water environment. The main conclusions drawn from this review are listed below:

1) All CoVs have a restricted stability in water media: 2 - 5 days in tap water and 2 - 6 days in wastewater were judged enough for 2-log reduction of SARS-CoV-2 titer [1].

2) Examining viable virus particles furnishes important data on the likely infectivity of a polluted specimen. Few studies followed the infectivity of SARSCoV-2 in influents and effluents of municipal WWTPs and in hospital wastewater [1].

3) CoVs could be spread mostly through airborne routes and the dangers linked with the likely water-mediated diffusion of the SARS-CoV-2 seem to be of low epidemiological importance. Nevertheless, circulation of SARS-CoV-2 can be potential through fomites, fecal-oral route and aerosolization of infected sewages from urinals, toilets and sewage pipeline. Thus, the preventive warnings relating to the observation of SARS-CoV-2 in wastewater need more tests [1].

4) SARS-CoV-2 is distinguished by a weak construction and is vulnerable to traditional disinfection technologies that have been demonstrated to be very efficient in their neutralization. Approximately $5 \mathrm{~min}$ of exposure to sodium hypochlorite $(1 \%)$, ethanol $(70 \%)$, iodine $(7.5 \%)$, soap solution and additional usual disinfectants was enough for reaching 7 - 8-log of SARS-CoV-2 titer decrease. Thermal treatment is efficacious in SARS-CoV-2 demobilization: $30 \mathrm{~min}$ at 56 or $5 \mathrm{~min}$ at $70^{\circ} \mathrm{C}$ were enough for attaining the total depletion of the infectivity. Further, SARS-CoV-2 remains vulnerable to sunlight and quickly demobilized by UV radiation. UV-C at $254 \mathrm{~nm}$ and intensity of $2.2 \mathrm{~mW} / \mathrm{cm}^{2}$ yields $3-\log$ of SARS-CoV-2 titer decrease in less than $3 \mathrm{~s}$ of application [1].

5) Large use of disinfectants has been related to ecological and human health troubles [149]; consequently for SARS-CoV-2 disinfection, usual injections of killing agents remain required for sanitation and for wastewater treatment [1] [128] [150].

\section{Acknowledgements}

The Research Deanship of University of Ha'il, Saudi Arabia, has funded this research through the Project RG-20 113.

\section{Conflicts of Interest}

The authors declare no conflicts of interest regarding the publication of this paper.

\section{References}

[1] Buonerba, A., Vermi Aizza Corpuz, M., Ballesteros, F., Choo, K.-H., Hasan, S.W., Korshin, G.V., Belgiorno, V., Barceló, D. and Naddeo, V. (2021) Coronavirus in Water Media: Analysis, Fate, Disinfection and Epidemiological Applications. Jour- 
nal of Hazardous Materials, 415, Article ID: 125580.

https://doi.org/10.1016/j.jhazmat.2021.125580

[2] Ghernaout, D. and Elboughdiri, N. (2020) Environmental Engineering for Stopping Viruses Pandemics. Open Access Library Journal, 7, e6299.

[3] Holshue, M.L., DeBolt, C., Lindquist, S., Lofy, K.H., Wiesman, J., Bruce, H., Spitters, C., Ericson, K., Wilkerson, S., Tural, A., Diaz, G., Cohn, A., Fox, L., Patel, A., Gerber, S.I., Kim, L., Tong, S., Lu, X., Lindstrom, S., Pallansch, M.A., Weldon, W.C., Biggs, H.M., Uyeki, T.M. and Pillai, S.K. (2020) First Case of 2019 Novel Coronavirus in the United States. The New England Journal of Medicine, 382, 929-936. https://doi.org/10.1056/NEJMoa2001191

[4] Corpuz, M.V.A., Buonerba, A., Vigliotta, G., Zarra, T., Ballesteros, F., Campiglia, P., Belgiorno, V., Korshin, G. and Naddeo, V. (2020) Viruses in Wastewater: Occurrence, Abundance and Detection Methods. Science of the Total Environment, 745, Article ID: 140910. https://doi.org/10.1016/j.scitotenv.2020.140910

[5] Ghernaout, D. and Elboughdiri, N. (2020) On the Other Side of Viruses in the Background of Water Disinfection. Open Access Library Journal, 7, e6374.

[6] Ghernaout, D. (2020) Water Treatment Challenges towards Viruses Removal. Open Access Library Journal, 7, e6408.

[7] Ghernaout, D., Elboughdiri, N. and Al Arni, S. (2020) New Insights towards Disinfecting Viruses-Short Notes. Journal of Water Reuse and Desalination, 10, 173186. https://doi.org/10.2166/wrd.2020.050

[8] Ghernaout, D. and Elboughdiri, N. (2021) Modeling Viruses' Isoelectric Points as a Milestone in Intensifying the Electrocoagulation Process for Their Elimination. Open Access Library Journal, 8, e7166. https://doi.org/10.4236/oalib.1107166

[9] Cui, J., Li, F. and Shi, Z.-L. (2019) Origin and Evolution of Pathogenic Coronaviruses. Nature Reviews Microbiology, 17, 181-192. https://doi.org/10.1038/s41579-018-0118-9

[10] Ghernaout, D. (2019) Virus Removal by Electrocoagulation and Electrooxidation: New Findings and Future Trends. Journal of Environmental Science and Allied Research, 2019, 85-90.

[11] Ghernaout, D. and Elboughdiri, N. (2020) Disinfecting Water: Plasma Discharge for Removing Coronaviruses. Open Access Library Journal, 7, e6314.

https://doi.org/10.4236/oalib.1106314

[12] Andersen, K.G., Rambaut, A., Lipkin, W.I., Holmes, E.C. and Garry, R.F. (2020) The Proximal Origin of SARS-CoV-2. Nature Medicine, 26, 450-452. https://doi.org/10.1038/s41591-020-0820-9

[13] Zhou, P., Yang, X.-L., Wang, X.-G., Hu, B., Zhang, L., Zhang, W., Si, H.R., Zhu, Y., Li, B., Huang, C.L., Chen, H.D., Chen, J., Luo, Y., Guo, H., Jiang, R.D., Liu, M.Q., Chen, Y., Shen, X.R., Wang, X., Zheng, X.S., Zhao, K., Chen, Q.J., Deng, F., Liu, L.L., Yan, B., Zhan, F.X., Wang, Y.Y., Xiao, G.F. and Shi, Z.L. (2020) A Pneumonia Outbreak Associated with a New Coronavirus of Probable Bat Origin. Nature, 579, 270-273. https://doi.org/10.1038/s41586-020-2012-7

[14] Asadi, S., Bouvier, N., Wexler, A.S. and Ristenpart, W.D. (2020) The Coronavirus Pandemic and Aerosols: Does COVID-19 Transmit via Expiratory Particles? Aerosol Science and Technology, 54, 635-638. https://doi.org/10.1080/02786826.2020.1749229

[15] Bourouiba, L. (2020) Turbulent Gas Clouds and Respiratory Pathogen Emissions: Potential Implications for Reducing Transmission of COVID-19. JAMA, 323, 18371838. https://doi.org/10.1001/jama.2020.4756 
[16] Van Doremalen, N., Bushmaker, T., Morris, D.H., Holbrook, M.G., Gamble, A., Williamson, B.N., Tamin, A., Harcourt, J.L., Thornburg, N.J., Gerber, S.I., LloydSmith, J.O., de Wit, E. and Munster, V.J. (2020) Aerosol and Surface Stability of SARS-CoV-2 as Compared with SARS-CoV-1. The New England Journal of Medicine, 382, 1564-1567. https://doi.org/10.1056/NEJMc2004973

[17] Lu, C.-W., Liu, X.-F. and Jia, Z.-F. (2020) 2019-nCoV Transmission through the Ocular Surface Must Not Be Ignored. The Lancet, 395, e39.

https://doi.org/10.1016/S0140-6736(20)30313-5

[18] Gupta, S., Parker, J., Smits, S., Underwood, J. and Dolwani, S. (2020) Persistent Viral Shedding of SARS-CoV-2 in Faeces-A Rapid Review. Colorectal Disease, 22, 611-620. https://doi.org/10.1111/codi.15138

[19] Gwenzi, W. (2020) Leaving No Stone Unturned in Light of the COVID-19 Faecal-Oral Hypothesis? A Water, Sanitation and Hygiene (WASH) Perspective Targeting Low-Income Countries. Science of the Total Environment, 753, Article ID: 141751. https://doi.org/10.1016/j.scitotenv.2020.141751

[20] Chan, K.H., Poon, L.L.L.M., Cheng, V.C.C., Guan, Y., Hung, I.F.N., Kong, J., Yam, L.Y.C., Seto, W.H., Yuen, K.Y. and Peiris, J.S.M. (2004) Detection of SARS Coronavirus in Patients with Suspected SARS. Emerging Infectious Diseases, 10, 294-299. https://doi.org/10.3201/eid1002.030610

[21] Ye, Y., Ellenberg, R.M., Graham, K.E. and Wigginton, K.R. (2016) Survivability, Partitioning, and Recovery of Enveloped Viruses in Untreated Municipal Wastewater. Environmental Science \& Technology, 50, 5077-5085. https://doi.org/10.1021/acs.est.6b00876

[22] Hung, L.S. (2003) The SARS Epidemic in Hong Kong: What Lessons Have We Learned? Journal of the Royal Society of Medicine, 96, 374-378. https://doi.org/10.1258/jrsm.96.8.374

[23] Matsui, S. (2005) Protecting Human and Ecological Health under Viral Threats in Asia. Water Science and Technology, 51, 91-97. https://doi.org/10.2166/wst.2005.0234

[24] Wrapp, D., Wang, N., Corbett, K.S., Goldsmith, J.A., Hsieh, C.-L., Abiona, O., Graham, B.S. and McLellan, J.S. (2020) Cryo-EM Structure of the 2019-nCoV Spike in the Prefusion Conformation. Science, 367, 1260-1263.

https://doi.org/10.1126/science.abb2507

[25] Yeo, C., Kaushal, S. and Yeo, D. (2020) Enteric Involvement of Coronaviruses: Is Faecal-Oral Transmission of SARS-CoV-2 Possible? The Lancet Gastroenterology and Hepatology, 5, 335-337. https://doi.org/10.1016/S2468-1253(20)30048-0

[26] Xiao, F., Sun, J., Xu, Y., Li, F., Huang, X., Li, H., Zhao, J., Huang, J. and Zhao, J. (2020) Infectious SARS-CoV-2 in Feces of Patient with Severe COVID-19. Emerging Infectious Diseases, 26, 1920-1922. https://doi.org/10.3201/eid2608.200681

[27] Bivins, A., Greaves, J., Fischer, R., Yinda, K.C., Ahmed, W., Kitajima, M., Munster, V.J. and Bibby, K. (2020) Persistence of SARS-CoV-2 in Water and Wastewater. Environmental Science \& Technology Letters, 7, 937-942.

https://doi.org/10.1021/acs.estlett.0c00730

[28] Ghernaout, D. (2018) Increasing Trends towards Drinking Water Reclamation from Treated Wastewater. World Journal of Applied Chemistry, 3, 1-9. https://doi.org/10.11648/j.wjac.20180301.11

[29] Ghernaout, D., Alshammari, Y. and Alghamdi, A. (2018) Improving Energetically Operational Procedures in Wastewater Treatment Plants. International Journal of Advanced and Applied Sciences, 5, 64-72. https://doi.org/10.21833/ijaas.2018.09.010 
[30] Al Arni, S., Amous, J. and Ghernaout, D. (2019) On the Perspective of Applying of a New Method for Wastewater Treatment Technology: Modification of the Third Traditional Stage with Two Units, One by Cultivating Microalgae and Another by Solar Vaporization. International Journal of Environmental Sciences \& Natural Resources, 16, Article ID: 555934. https://doi.org/10.19080/IJESNR.2019.16.555934

[31] Ghernaout, D. and Elboughdiri, N. (2020) Urgent Proposals for Disinfecting Hospital Wastewaters during COVID-19 Pandemic. Open Access Library Journal, 7, e6373. https://doi.org/10.4236/oalib.1106373

[32] Ghernaout, D. and Ghernaout, B. (2020) Controlling COVID-19 Pandemic through Wastewater Monitoring. Open Access Library Journal, 7, e6411. https://doi.org/10.4236/oalib.1106411

[33] Arslan, M., Xu, B. and Gamal El-Din, M. (2020) Transmission of SARS-CoV-2 via Fecal-Oral and Aerosols-Borne Routes: Environmental Dynamics and Implications for Wastewater Management in Underprivileged Societies. Science of the Total Environment, 743, Article ID: 140709. https://doi.org/10.1016/j.scitotenv.2020.140709

[34] El Baz, S. and Imziln, B. (2020) Can Aerosols and Wastewater Be Considered as Potential Transmissional Sources of COVID-19 to Humans? European Journal of Environment and Public Health, 4, em0047. https://doi.org/10.29333/ejeph/8324

[35] Schuit, M., Ratnesar-Shumate, S., Yolitz, J., Williams, G., Weaver, W., Green, B., Miller, D., Krause, M., Beck, K., Wood, S., Holland, B., Bohannon, J., Freeburger, D., Hooper, I., Biryukov, J., Altamura, L.A., Wahl, V., Hevey, M. and Dabisch, P. (2020) Airborne SARS-CoV-2 Is Rapidly Inactivated by Simulated Sunlight. The Journal of Infectious Diseases, 222, 564-571. https://doi.org/10.1093/infdis/jiaa334

[36] Ghernaout, D., Elboughdiri, N., Ghareba, S. and Salih, A. (2020) Coagulation Process for Removing Algae and Algal Organic Matter-An Overview. Open Access Library Journal, 7, e6272. https://doi.org/10.4236/oalib.1106272

[37] Ghernaout, D. and Elboughdiri, N. (2020) Eliminating Cyanobacteria and Controlling Algal Organic Matter-Short Notes. Open Access Library Journal, 7, e6252. https://doi.org/10.4236/oalib.1106252

[38] Ghernaout, D., Ghernaout, B. and Kellil, A. (2009) Natural Organic Matter Removal and Enhanced Coagulation as a Link between Coagulation and Electrocoagulation. Desalination and Water Treatment, 2, 203-222.

https://doi.org/10.5004/dwt.2009.116

[39] Casanova, L., Rutala, W.A., Weber, D.J. and Sobsey, M.D. (2009) Survival of Surrogate Coronaviruses in Water. Water Research, 43, 1893-1898. https://doi.org/10.1016/j.watres.2009.02.002

[40] Wigginton, K.R., Ye, Y. and Ellenberg, R.M. (2015) Emerging Investigators Series: the Source and Fate of Pandemic Viruses in the Urban Water Cycle. Environmental Science: Water Research \& Technology, 1, 735-746.

https://doi.org/10.1039/C5EW00125K

[41] Bhardwaj, R. and Agrawal, A. (2020) Tailoring Surface Wettability to Reduce Chances of Infection of COVID-19 by a Respiratory Droplet and to Improve the Effectiveness of Personal Protection Equipment. Physics of Fluids, 32, Article ID: 081702. https://doi.org/10.1063/5.0020249

[42] Ghernaout, D. (2020) Charge Neutralization in the Core of Plasma Treatment. Open Access Library Journal, 7, e6434.

[43] Ghernaout, D. (2017) Environmental Principles in the Holy Koran and the Sayings of the Prophet Muhammad. American Journal of Environmental Protection, 6, 7579. https://doi.org/10.11648/j.ajep.20170603.13 
[44] Ghernaout, D., Ghernaout, B. and Naceur, M.W. (2011) Embodying the Chemical Water Treatment in the Green Chemistry-A Review. Desalination, 271, 1-10. https://doi.org/10.1016/j.desal.2011.01.032

[45] Ghernaout, D. (2018) Electrocoagulation Process: Achievements and Green Perspectives. Colloid and Surface Science, 3, 1-5. https://doi.org/10.11648/j.css.20180301.11

[46] Ghernaout, D. (2019) Greening Electrocoagulation Process for Disinfecting Water. Applied Engineering, 3, 27-31.

[47] Ghernaout, D. and Elboughdiri, N. (2019) Water Disinfection: Ferrate(VI) as the Greenest Chemical-A Review. Applied Engineering, 3, 171-180.

[48] Ghernaout, D. (2019) Reviviscence of Biological Wastewater Treatment-A Review. Applied Engineering, 3, 46-55.

[49] Ghernaout, D. and Elboughdiri, N. (2019) Upgrading Wastewater Treatment Plant to Obtain Drinking Water. Open Access Library Journal, 6, e5959. https://doi.org/10.4236/oalib.1105959

[50] Ghernaout, D. and Elboughdiri, N. (2020) Electrochemical Technology for Wastewater Treatment: Dares and Trends. Open Access Library Journal, 7, e6020.

[51] Ghernaout, D., Elboughdiri, N. and Ghareba, S. (2020) Fenton Technology for Wastewater Treatment: Dares and Trends. Open Access Library Journal, 7, e6045. https://doi.org/10.4236/oalib.1106045

[52] Ghernaout, D. and Elboughdiri, N. (2020) On the Treatment Trains for Municipal Wastewater Reuse for Irrigation. Open Access Library Journal, 7, e6088.

[53] Ghernaout, D. and Elboughdiri, N. (2020) Advanced Oxidation Processes for Wastewater Treatment: Facts and Future Trends. Open Access Library Journal, 7, e6139.

[54] Mirskaya, E. and Agranovski, I.E. (2018) Sources and Mechanisms of Bioaerosol Generation in Occupational Environments. Critical Reviews in Microbiology, 44, 739-758. https://doi.org/10.1080/1040841X.2018.1508125

[55] Ghernaout, D. and Elboughdiri, N. (2020) Domestic Wastewater Treatment: Difficulties and Reasons, and Prospective Solutions-China as an Example. Open Access Library Journal, 7, e6141.

[56] Masclaux, F.G., Hotz, P., Gashi, D., Savova-Bianchi, D. and Oppliger, A. (2014) Assessment of Airborne Virus Contamination in Wastewater Treatment Plants. Environmental Research, 133, 260-265. https://doi.org/10.1016/j.envres.2014.06.002

[57] Ghernaout, D., Moulay, S., Ait Messaoudene, N., Aichouni, M., Naceur, M.W. and Boucherit, A. (2014) Coagulation and Chlorination of NOM and Algae in Water Treatment: A Review. International Journal of Environmental Monitoring and Analysis, 2, 23-34. https://doi.org/10.11648/j.ijema.s.2014020601.14

[58] Ghernaout, D. (2017) Water Treatment Chlorination: An Updated Mechanistic Insight Review. Chemistry Research Journal, 2, 125-138.

[59] Ghernaout, D., Alghamdi, A., Aichouni, M. and Touahmia, M. (2018) The Lethal Water Tri-Therapy: Chlorine, Alum, and Polyelectrolyte. World Journal of Applied Chemistry, 3, 65-71. https://doi.org/10.11648/j.wjac.20180302.14

[60] Ghernaout, D., Naceur, M.W. and Aouabed, A. (2011) On the Dependence of Chlorine By-Products Generated Species Formation of the Electrode Material and Applied Charge during Electrochemical Water Treatment. Desalination, 270, 9-22. https://doi.org/10.1016/j.desal.2011.01.010

[61] Ghernaout, D. and Elboughdiri, N. (2020) Solar Treatment in the Core of the New Disinfection Technologies. Chemical Science and Engineering Research, 2, 6-11. 
https://doi.org/10.36686/Ariviyal.CSER.2020.02.04.014

[62] Rabenau, H.F., Cinatl, J., Morgenstern, B., Bauer, G., Preiser, W. and Doerr, H.W. (2005) Stability and Inactivation of SARS Coronavirus. Medical Microbiology and Immunology, 194, 1-6. https://doi.org/10.1007/s00430-004-0219-0

[63] Wang, X.-W., Li, J.-S., Jin, M., Zhen, B., Kong, Q.-X., Song, N., Xiao, W.J., Yin, J., Wei, W., Wang, G.J., Si, B., Guo, B.Z., Liu, C., Ou, G.R., Wang, M.N., Fang, T.Y., Chao, F.H. and Li, J.W. (2005) Study on the Resistance of Severe Acute Respiratory Syndrome-Associated Coronavirus. Journal of Virological Methods, 126, 171-177. https://doi.org/10.1016/j.jviromet.2005.02.005

[64] Sizun, J., Yu, M.W.N. and Talbot, P.J. (2000) Survival of Human Coronaviruses 229E and OC43 in Suspension and after Drying on Surfaces: A Possible Source of Hospital-Acquired Infections. Journal of Hospital Infection, 46, 55-60. https://doi.org/10.1053/jhin.2000.0795

[65] Chin, A.W.H., Chu, J.T.S., Perera, M.R.A., Hui, K.P.Y., Yen, H.-L., Chan, M.C.W., Peiris, M. and Poon, L.L.M. (2020) Stability of SARS-CoV-2 in Different Environmental Conditions. The Lancet Microbe, 1, e10. https://doi.org/10.1016/S2666-5247(20)30003-3

[66] Tian, Y., Rong, L., Nian, W. and He, Y. (2020) Review Article: Gastrointestinal Features in COVID-19 and the Possibility of Faecal Transmission. Alimentary Pharmacology \& Therapeutics, 51, 843-851. https://doi.org/10.1111/apt.15731

[67] La Rosa, G., Mancini, P., Bonanno Ferraro, G., Veneri, C., Laconelli, M., Bonadonna, L., Lucentini, L. and Suffredini, E. (2021) SARS-CoV-2 Has Been Circulating in Northern Italy since December 2019: Evidence from Environmental Monitoring. Science of the Total Environment, 750, Article ID: 141711. https://doi.org/10.1016/j.scitotenv.2020.141711

[68] Medema, G., Heijnen, L., Elsinga, G., Italiaander, R. and Brouwer, A. (2020) Presence of SARS-Coronavirus-2 RNA in Sewage and Correlation with Reported COVID-19 Prevalence in the Early Stage of the Epidemic in the Netherlands. Environmental Science \& Technology Letters, 7, 511-516. https://doi.org/10.1021/acs.estlett.0c00357

[69] Ghernaout, D. (2014) The Hydrophilic/Hydrophobic Ratio vs. Dissolved Organics Removal by Coagulation-A Review. Journal of King Saud University-Science, 26, 169-180. https://doi.org/10.1016/j.jksus.2013.09.005

[70] Ghernaout, D. (2019) Greening Cold Fusion as an Energy Source for Water Treatment Distillation-A Perspective. American Journal of Quantum Chemistry and Molecular Spectroscopy, 3, 1-5.

[71] Ghernaout, D. and Elboughdiri, N. (2020) UV-C/ $\mathrm{H}_{2} \mathrm{O}_{2}$ and Sunlight $/ \mathrm{H}_{2} \mathrm{O}_{2}$ in the Core of the Best Available Technologies for Dealing with Present Dares in Domestic Wastewater Reuse. Open Access Library Journal, 7, e6161. https://doi.org/10.4236/oalib.1106161

[72] Ghernaout, D. and Elboughdiri, N. (2020) Vacuum-UV Radiation at $185 \mathrm{~nm}$ for Disinfecting Water. Chemical Science and Engineering Research, 2, 12-17. https://doi.org/10.36686/Ariviyal.CSER.2020.02.04.015

[73] Ghernaout, D. and Ghernaout, B. (2010) From Chemical Disinfection to Electrodisinfection: The Obligatory Itinerary? Desalination, and Water Treatment, 16, 156175. https://doi.org/10.5004/dwt.2010.1085

[74] Ghernaout, D. (2018) Disinfection and DBPs Removal in Drinking Water Treatment: A Perspective for a Green Technology. International Journal of Advanced and Applied Sciences, 5, 108-117. https://doi.org/10.21833/ijaas.2018.02.018 
[75] Ghernaout, D., Touahmia, M. and Aichouni, M. (2019) Disinfecting Water: Electrocoagulation as an Efficient Process. Applied Engineering, 3, 1-12.

[76] Ghernaout, D. and Elboughdiri, N. (2020) Is Not It Time to Stop Using Chlorine for Treating Water? Open Access Library Journal, 7, e6007.

[77] Ghernaout, D. (2017) Microorganisms' Electrochemical Disinfection Phenomena. EC Microbiology, 9, 160-169.

[78] Ghernaout, D., Alghamdi, A. and Ghernaout, B. (2019) Microorganisms' Killing: Chemical Disinfection vs. Electrodisinfection. Applied Engineering, 3, 13-19.

[79] Ghernaout, D. and Ghernaout, B. (2012) On the Concept of the Future Drinking Water Treatment Plant: Algae Harvesting from the Algal Biomass for Biodiesel Production-A Review. Desalination, and Water Treatment, 49, 1-18. https://doi.org/10.1080/19443994.2012.708191

[80] Ghernaout, D., Badis, A., Braikia, G., Matâam, N., Fekhar, M., Ghernaout, B. and Boucherit, A. (2017) Enhanced Coagulation for Algae Removal in a Typical Algeria Water Treatment Plant. Environmental Engineering and Management Journal, 16, 2303-2315. https://doi.org/10.30638/eemj.2017.238

[81] Alshammari, Y., Ghernaout, D., Aichouni, M. and Touahmia, M. (2018) Improving Operational Procedures in Riyadh's (Saudi Arabia) Water Treatment Plants Using Quality Tools. Applied Engineering, 2, 60-71.

[82] Ghernaout, D. (2019) Brine Recycling: Towards Membrane Processes as the Best Available Technology. Applied Engineering, 3, 71-84.

[83] Ghernaout, D. (2020) New Configurations and Techniques for Controlling Membrane Bioreactor (MBR) Fouling. Open Access Library Journal, 7, e6579.

[84] Khan, M.I., Shanableh, A., Elboughdiri, N., Kriaa, K., Ghernaout, D., Ghareba, S., Khraisheh, M. and Lashari, M.H. (2021) Higher acid Recovery Efficiency of Novel Functionalized Inorganic/Organic Composite Anion Exchange Membranes from Acidic Wastewater. Membranes, 11, 133. https://doi.org/10.3390/membranes11020133

[85] Irki, S., Kasbadji-Merzouk, N., Hanini, S. and Ghernaout, D. (2020) Modelling of the Coupling of Desalination Plants with the Thermal Solar Energy System. Water Supply, 20, 1807-1822. https://doi.org/10.2166/ws.2020.092

[86] Darnell, M.E.R. and Taylor, D.R. (2006) Evaluation of Inactivation Methods for Severe acute Respiratory Syndrome Coronavirus in Noncellular Blood Products. Transfusion, 46, 1770-1777. https://doi.org/10.2166/ws.2020.092https://doi.org/10.2166/ws.2020.092

[87] John, D.E. and Rose, J.B. (2005) Review of Factors Affecting Microbial Survival in Groundwater. Environmental Science \& Technology, 39, 7345-7356. https://doi.org/10.1021/es047995w

[88] Pratelli, A. (2008) Canine Coronavirus Inactivation with Physical and Chemical Agents. The Veterinary Journal, 177, 71-79.

https://doi.org/10.1016/j.tvjl.2007.03.019

[89] Auler, A.C., Cássaro, F.A.M., da Silva, V.O. and Pires, L.F. (2020) Evidence That High Temperatures and Intermediate Relative Humidity Might Favor the Spread of COVID-19 in Tropical Climate: A Case Study for the Most Affected Brazilian Cities. Science of the Total Environment, 729, Article ID: 139090. https://doi.org/10.1016/j.scitotenv.2020.139090

[90] Tobías A. and Molina, T. (2020) Is Temperature Reducing the Transmission of COVID-19? Environmental Research, 186, Article ID: 109553. 
https://doi.org/10.1016/j.envres.2020.109553

[91] Ghernaout, D. (2013) The Best Available Technology of Water/Wastewater Treatment and Seawater Desalination: Simulation of the Open Sky Seawater Distillation. Green and Sustainable Chemistry, 3, 68-88. https://doi.org/10.4236/gsc.2013.32012

[92] Ghernaout, D. (2020) Demobilizing Antibiotic-Resistant Bacteria and Antibiotic Resistance Genes by Electrochemical Technology: New Insights. Open Access Library Journal, 7, e6685. https://doi.org/10.4236/oalib.1106685

[93] Ghernaout, D. and Elboughdiri, N. (2020) Antibiotics Resistance in Water Mediums: Background, Facts, and Trends. Applied Engineering, 4, 1-6.

[94] Ghernaout, D. and Elboughdiri, N. (2020) Removing Antibiotic-Resistant Bacteria (ARB) Carrying Genes (ARGs): Challenges and Future Trends. Open Access Library Journal, 7, e6003. https://doi.org/10.4236/oalib.1106003

[95] Ghernaout, D. and Elboughdiri, N. (2020) Should We Forbid the Consumption of Antibiotics to Stop the Spread of Resistances in Nature? Open Access Library Journal, 7, e6138.

[96] Qiu, Y., Li, Q., Lee, B.E., Ruecker, N.J., Neumann, N.F., Ashbolt, N.J. and Pang, X. (2018) UV Inactivation of Human Infectious Viruses at Two Full-Scale Wastewater Treatment Plants in Canada. Water Research, 147, 73-81. https://doi.org/10.1016/j.watres.2018.09.057

[97] Kariwa, H., Fujii, N. and Takashima, I. (2006) Inactivation of SARS Coronavirus by Means of Povidone-Iodine, Physical Conditions and Chemical Reagents. Dermatology, 212, S119-S123. https://doi.org/10.1159/000089211

[98] Ratnesar-Shumate, S., Williams, G., Green, B., Krause, M., Holland, B., Wood, S., Bohannon, J., Boydston, J., Freeburger, D., Hooper, I., Beck, K., Yeager, J., Altamura, L.A., Biryukov, J., Yolitz, J., Schuit, M., Wahl, V., Hevey, M. and Dabisch, P. (2020) Simulated Sunlight Rapidly Inactivates SARS-CoV-2 on Surfaces. The Journal of Infectious Diseases, 222, 214-222. https://doi.org/10.1093/infdis/jiaa274

[99] Tang, L., Liu, M., Ren, B., Wu, Z., Yu, X., Peng, C. and Tian, J. (2021) Sunlight Ultraviolet Radiation Dose Is Negatively Correlated with the Percent Positive of SARSCoV-2 and Four Other Common Human Coronaviruses in the U.S. Science of the Total Environment, 751, Article ID: 141816.

https://doi.org/10.1016/j.scitotenv.2020.141816

[100] Heilingloh, C.S., Aufderhorst, U.W., Schipper, L., Dittmer, U., Witzke, O., Yang, D., Zheng, X., Sutter, K., Trilling, M., Alt, M., Steinmann, E. and Krawczyk, A. (2020) Susceptibility of SARS-CoV-2 to UV Irradiation. American Journal of Infection Control, 48, 1273-1275. https://doi.org/10.1016/j.ajic.2020.07.031

[101] Sabino, C.P., Sellera, F.P., Sales-Medina, D.F., Machado, R.R.G., Durigon, E.L., Freitas-Junior, L.H. and Ribeiro, M.S. (2020) UV-C (254 nm) Lethal Doses for SARSCoV-2. Photodiagnosis and Photodynamic Therapy, 32, Article ID: 101995. https://doi.org/10.1016/j.pdpdt.2020.101995

[102] Eggers, M., Eickmann, M. and Zorn, J. (2015) Rapid and Effective Virucidal Activity of Povidone-Iodine Products against Middle East Respiratory Syndrome Coronavirus (MERS-CoV) and Modified Vaccinia Virus Ankara (MVA). Infectious Diseases and Therapy, 4, 491-501. https://doi.org/10.1007/s40121-015-0091-9

[103] Lamarre, A. and Talbot, P.J. (1989) Effect of $\mathrm{pH}$ and Temperature on the Infectivity of Human Coronavirus 229E. Canadian Journal of Microbiology, 35, 972-974. https://doi.org/10.1139/m89-160

[104] Sturman, L.S., Ricard, C.S. and Holmes, K.V. (1990) Conformational Change of the 
Coronavirus Peplomer Glycoprotein at pH 8.0 and 37 Degrees C Correlates with Virus Aggregation and Virus-Induced Cell Fusion. Journal of Virology, 64, 30423050. https://doi.org/10.1128/JVI.64.6.3042-3050.1990

[105] Pocock, D.H. and Garwes, D.J. (1975) The Influence of $\mathrm{pH}$ on the Growth and Stability of Transmissible Gastroenteritis Virus in Vitro. Archives of Virology, 49, 239247. https://doi.org/10.1007/BF01317542

[106] Geller, C., Varbanov, M. and Duval, R.E. (2012) Human Coronaviruses: Insights into Environmental Resistance and Its Influence on the Development of New Antiseptic Strategies. Viruses, 4, 3044-3068. https://doi.org/10.3390/v4113044

[107] Ghernaout, D., Elboughdiri, N., Ghareba, S. and Salih, A. (2020) Disinfecting Water with the Carbon Fiber-Based Flow-Through Electrode System (FES): Towards Axial Dispersion and Velocity Profile. Open Access Library Journal, 7, e6238. https://doi.org/10.4236/oalib.1106238

[108] Ghernaout, D., Elboughdiri, N., Ghareba, S. and Salih, A. (2020) Electrochemical Advanced Oxidation Processes (EAOPs) for Disinfecting Water-Fresh Perspectives. Open Access Library Journal, 7, e6257. https://doi.org/10.4236/oalib.1106257

[109] Ghernaout, D. and Elboughdiri, N. (2020) Towards Enhancing Ozone Diffusion for Water Disinfection-Short Notes. Open Access Library Journal, 7, e6253.

[110] Ghernaout, D. and Elboughdiri, N. (2020) Disinfection By-Products: Presence and Elimination in Drinking Water. Open Access Library Journal, 7, e6140.

[111] Ghernaout, D. and Elboughdiri, N. (2020) Controlling Disinfection By-Products Formation in Rainwater: Technologies and Trends. Open Access Library Journal, 7, e6162.

[112] Boucherit, A., Moulay, S., Ghernaout, D., Al-Ghonamy, A.I., Ghernaout, B., Naceur, M.W., Ait Messaoudene, N., Aichouni, M., Mahjoubi, A.A. and Elboughdiri, N.A. (2015) New Trends in Disinfection By-Products Formation upon Water Treatment. Journal of Research \& Developments in Chemistry, 2015, Article ID: 628833. https://doi.org/10.5171/2015.628833

[113] Ghernaout, D., Aichouni, M. and Touahmia, M. (2019) Mechanistic Insight into Disinfection by Electrocoagulation-A Review. Desalination, and Water Treatment, 141, 68-81. https://doi.org/10.5004/dwt.2019.23457

[114] Ghernaout, D. (2019) Electrocoagulation and Electrooxidation for Disinfecting Water: New Breakthroughs and Implied Mechanisms. Applied Engineering, 3, 125-133.

[115] Ghernaout, D. and Elboughdiri, N. (2019) Electrocoagulation Process Intensification for Disinfecting Water-A Review. Applied Engineering, 3, 140-147.

[116] Ghernaout, D. and Elboughdiri, N. (2019) Iron Electrocoagulation Process for Disinfecting Water-A Review. Applied Engineering, 3, 154-158.

[117] Ghernaout, D. (2019) Disinfection via Electrocoagulation Process: Implied Mechanisms and Future Tendencies. EC Microbiology, 15, 79-90.

[118] Ghernaout, D. and Elboughdiri, N. (2019) Mechanistic Insight into Disinfection Using Ferrate(VI). Open Access Library Journal, 6, e5946.

[119] Ghernaout, D. and Elboughdiri, N. (2020) Strategies for Reducing Disinfection ByProducts Formation during Electrocoagulation. Open Access Library Journal, 7, e6076.

[120] Ghernaout, D. and Elboughdiri, N. (2020) Electrocoagulation Process in the Context of Disinfection Mechanism. Open Access Library Journal, 7, e6083.

[121] Ghernaout, D., Elboughdiri, N., Alghamdi, A. and Ghernaout, B. (2020) Trends in Decreasing Disinfection By-Products Formation during Electrochemical Technolo- 
gies. Open Access Library Journal, 7, e6337. https://doi.org/10.4236/oalib.1106337

[122] Ghernaout, D. and Elboughdiri, N. (2020) Foresight Look on the Disinfection ByProducts Formation. Open Access Library Journal, 7, e6349.

[123] Darnell, M.E.R., Subbarao, K., Feinstone, S.M. and Taylor, D.R. (2004) Inactivation of the Coronavirus That Induces Severe Acute Respiratory Syndrome, SARS-CoV. Journal of Virological Methods, 121, 85-91. https://doi.org/10.1016/j.jviromet.2004.06.006

[124] Dunkin, N., Weng, S., Schwab, K.J., McQuarrie, J., Bell, K. and Jacangelo, J.G. (2017) Comparative Inactivation of Murine Norovirus and MS2 Bacteriophage by Peracetic Acid and Monochloramine in Municipal Secondary Wastewater Effluent. Environmental Science \& Technology, 51, 2972-2981. https://doi.org/10.1021/acs.est.6b05529

[125] Ghernaout, D. (2020) Electric Field (EF) in the Core of the Electrochemical (EC) Disinfection. Open Access Library Journal, 7, e6587.

[126] Ghernaout, D. and Elboughdiri, N. (2020) Disinfection By-Products (DBPs) Control Strategies in Electrodisinfection. Open Access Library Journal, 7, e6396.

https://doi.org/10.4236/oalib.1106396

[127] Zhang, D., Ling, H., Huang, X., Li, J., Li, W., Yi, C., Zhang, T., Jiang, Y., He, Y., Deng, S., Zhang, X., Wang, X., Liu, Y., Li, G. and Qu, J. (2020) Potential Spreading Risks and Disinfection Challenges of Medical Wastewater by the Presence of Severe Acute Respiratory Syndrome Coronavirus 2 (SARS-CoV-2) Viral RNA in Septic Tanks of Fangcang Hospital. Science of the Total Environment, 741, Article ID: 140445. https://doi.org/10.1016/j.scitotenv.2020.140445

[128] Ghernaout, D. and Elboughdiri, N. (2020) Disinfection By-Products Regulation: Zero ng/L Target. Open Access Library Journal, 7, e6382.

[129] Ghernaout, D. (2020) Natural Organic Matter Removal in the Context of the Performance of Drinking Water Treatment Processes-Technical Notes. Open Access Library Journal, 7, e6751.

[130] Ghernaout, D., Alshammari, Y., Alghamdi, A., Aichouni, M., Touahmia, M. and Ait Messaoudene, N. (2018) Water Reuse: Extenuating Membrane Fouling in Membrane Processes. International Journal of Environmental Chemistry, 2, 1-12. https://doi.org/10.11648/j.ajche.20180602.12

[131] Ghernaout, D., Elboughdiri, N. and Al Arni, S. (2019) Water Reuse (WR): Dares, Restrictions, and Trends. Applied Engineering, 3, 159-170.

[132] Adcock, N.J., Rice, E.W., Sivaganesan, M., Brown, J.D., Stallknecht, D.E. and Swayne, D.E. (2009) The Use of Bacteriophages of the Family Cystoviridae as Surrogates for H5N1 Highly Pathogenic Avian Influenza Viruses in Persistence and Inactivation Studies. Journal of Environmental Science and Health, Part A, 44, 1362-1366. https://doi.org/10.1080/10934520903217054

[133] Ghernaout, D., Elboughdiri, N. and Ghareba, S. (2019) Drinking Water Reuse: One-Step Closer to Overpassing the "Yuck Factor". Open Access Library Journal, 6, e5895. https://doi.org/10.4236/oalib.1105895

[134] Casanova, L.M. and Weaver, S.R. (2015) Inactivation of an Enveloped Surrogate Virus in Human Sewage, Environmental Science \& Technology Letters, 29, 76-78. https://doi.org/10.1021/acs.estlett.5b00029

[135] Ghernaout, D., Ghernaout, B. and Boucherit, A. (2008) Effect of pH on Electrocoagulation of Bentonite Suspensions in Batch Using Iron Electrodes. Journal of Dispersion Science and Technology, 29, 1272-1275. https://doi.org/10.1080/01932690701857483 
[136] Ghernaout, D., Naceur, M.W. and Ghernaout, B. (2011) A Review of Electrocoagulation as a Promising Coagulation Process for Improved Organic and Inorganic Matters Removal by Electrophoresis and Electroflotation. Desalination, and Water Treatment, 28, 287-320. https://doi.org/10.5004/dwt.2011.1493

[137] Ghernaout, D., Badis, A., Ghernaout, B. and Kellil, A. (2008) Application of Electrocoagulation in Escherichia coli Culture and Two Surface Waters. Desalination, 219, 118-125. https://doi.org/10.1016/j.desal.2007.05.010

[138] Belhout, D., Ghernaout, D., Djezzar-Douakh, S. and Kellil, A. (2010) Electrocoagulation of a Raw Water of Ghrib Dam (Algeria) in Batch Using Iron Electrodes. Desalination, and Water Treatment, 16, 1-9. https://doi.org/10.5004/dwt.2010.1081

[139] Ghernaout, D., Al-Ghonamy, A.I., Boucherit, A., Ghernaout, B., Naceur, M.W., Ait Messaoudene, N., Aichouni, M., Mahjoubi, A.A. and Elboughdiri, N.A. (2015) Brownian Motion and Coagulation Process. American Journal of Environmental Protection, 4, 1-15. https://doi.org/10.11648/j.ajeps.s.2015040501.11

[140] Ghernaout, B., Ghernaout, D. and Saiba, A. (2010) Algae and Cyanotoxins Removal by Coagulation/Flocculation: A Review. Desalination, and Water Treatment, 20, 133-143. https://doi.org/10.5004/dwt.2010.1202

[141] Ghernaout, D. (2017) Water Reuse (WR): The Ultimate and Vital Solution for Water Supply Issues. International Journal of Sustainable Development Research, 3, 3646. https://doi.org/10.11648/j.ijsdr.20170304.12

[142] Ghernaout, D., Elboughdiri, N. and Alghamdi, A. (2019) Direct Potable Reuse: The Singapore NEWater Project as a Role Model. Open Access Library Journal, 6, e5980. https://doi.org/10.4236/oalib.1105980

[143] Ghernaout, D. (2019) Aeration Process for Removing Radon from Drinking Water-A Review. Applied Engineering, 3, 32-45.

[144] Ghernaout, D., Benblidia, C. and Khemici, F. (2015) Microalgae Removal from Ghrib Dam (Ain Defla, Algeria) Water by Electroflotation Using Stainless Steel Electrodes. Desalination, and Water Treatment, 54, 3328-3337. https://doi.org/10.1080/19443994.2014.907749

[145] Kellali, Y. and Ghernaout, D. (2019) Physicochemical and Algal Study of Three Dams (Algeria) and Removal of Microalgae by Enhanced Coagulation, Applied Engineering, 3, 56-64.

[146] Ghernaout, D. (2020) Enhanced Coagulation: Promising Findings and Challenges. Open Access Library Journal, 7, e6569.

[147] Ghernaout, D. (2020) Water Treatment Coagulation: Dares and Trends. Open Access Library Journal, 7, e6636.

[148] Ghernaout, D. and Elboughdiri, N. (2019) Water Reuse: Emerging Contaminants Elimination-Progress and Trends. Open Access Library Journal, 6, e5981.

[149] Ghernaout, D. and Elboughdiri, N. (2020) Magnetic Field Application: An Underappreciated Outstanding Technology. Open Access Library Journal, 7, e6000.

[150] Ghernaout, D. and Elboughdiri, N. (2020) Dealing with Cyanobacteria and Cyanotoxins: Engineering Viewpoints. Open Access Library Journal, 7, e6363. 